\title{
THE POTENTIAL OF NANOCELLULOSE FROM Acacia mangium PULP FOR SPECIALTY PAPER MAKING
}

\author{
Nursyamsu Bahar ${ }^{1}$, Taufan Hidayat, Nina Elyani, Ike Rostika \\ Center for Pulp and Paper, Ministry of Industry \\ Jl. Raya Dayeuhkolot No. 132, Bandung 40258, Indonesia \\ 1'baharnus@yahoo.co.uk
}

Diterima : 20 Maret 2013, Revisi akhir : 16 Mei 2013, Disetujui terbit : 30 Mei 2013

\section{POTENSI NANOSELULOSA DARI PULP Acacia mangium UNTUK PEMBUATAN KERTAS KHUSUS}

\begin{abstract}
ABSTRAK
Tujuan dari penelitian ini adalah menggunakan nanoselulosa sebagai additive untuk meningkatkan kekuatan pada pembuatan kertas serta mengurangi energi proses penggilingan dan penggunaan NBKP serta diaplikasikan untuk kertas khusus. Pada penelitian ini nanoselulosa dibuat dari pulp Acacia mangium dalam air menggunakan disc refiner dan di buat homogen dengan ultra turrax dan ultra sonic. Penelitian ini dilakukan dengan tiga variasi ukuran partikel, lima variasi konsentrasi nanoselulosa, dan dua variasi komposisi pulp. Nanoselulosa ditambahkan pada stok dari pulp kayudaun (LBKP) dan pulp kayujarum (NBKP) pada pembuatan lembaran kertas. Struktur nanoselulosa diuji dengan menggunakan XRD, SEM, TEM dan PSA serta kekuatan fisik kertas ditentukan dengan menggunakan standard TAPPI dan SNI. Hasil penelitian menunjukkan bahwa partikel dengan ukuran yang lebih kecil memberikan efek peningkatan kekuatan yang lebih tinggi. Penambahan $2 \%$ nanoselulosa $(70 \mathrm{~nm})$ meningkatkan elongation sebanyak $24 \%$ dan TEA $50 \%$ sedangkan porositas turun sebanyak $50 \%$, Hal ini menunjukkan bahwa nanoselulosa dapat digunakan untuk pembuatan kertas khusus seperti kertas sekuritas yang memerlukan kekuatan yang tinggi dan kertas glasin yang memerlukan porositas yang rendah dan untuk menghindarkan dari penetrasi minyak dan digunakan untuk kemasan dari bahan yang berminyak.
\end{abstract}

Kata kunci: nanoselulosa, Acacia mangium, reinforcing agent, kertas khusus

\begin{abstract}
The goals of this research is to use nanocellulose as an additive for reinforcing agent in papermaking for reducing the beating process and the amount of NBKP continue with applying to specialty paper. In this research, nanocellulose was created from Acacia mangium pulp in water using disc refiner and made them homogenized with ultra turrax and ultra sonic as homogenizer. Research had been conducted in three variations of particle sizes, five variations of nanocellulose concentrations and 2 two variations of pulp compositions. The nanocellulose was added to the stock of Leaf Bleach Kraft Pulp (LBKP) and Needle Bleach Kraft Pulp (NBKP) for sheet papermaking. The structure of nanocellulose was determined by XRD, SEM, TEM, and PSA. The physical property of paper was determined by TAPPI standard and SNI.. The result showed that smaller particle gave higher reinforcing effect. The addition of $2 \%$ of nanocellulose $(70 \mathrm{~nm})$ increased the elongation by $24 \%$ and TEA by $50 \%$ while porosity decreased by $50 \%$. It showed that nanocellulose have great potential as reinforcing agent in papermaking. It can be used in specialty paper such as security paper which requires high strength and glassine paper, which needs low porosity to reserve its oil penetration and use for oily product packaging.
\end{abstract}

Keywords: nanocellulose, Acacia mangium, reinforcing agent, specialty paper 


\section{INTRODUCTION}

Paper made from natural cellulose fiber and artificial fiber had grammage lower than $225 \mathrm{~g} / \mathrm{m}^{2}$ (SNI 14-0581-89-A). There are three groups of paper, art paper, industrial paper and structural paper. Newspaper, books, magazine, writing, and printing paper are art paper. Wrapping paper, packaging paper and board are industrial paper while tissue is structural paper (Klush, 1976). Specialty paper is made for special needed such as security paper, stamp, greaseproof paper, parchment paper, and glassine paper. This paper need high physical properties and limited in quantity.

The physical property of paper, wet and dry strength is improved by adding additive and filler. The good dispersion of additive and filler makes the uniformity of surface, dimension stability and unchanging quality in usage. The good surface also depends on the fibre bonding (Kocurek, 1983).

There are two ways to produce nanocellulose, i.e. physical method and chemical method. In physical method cellulose is milled by using HEM, disc refiner or stone refiner, and continued to mix by using ultra turrax and high pressure homogenizer (Bahar et al., 2010).

Nanocellulose from Agave sisalana and bamboo (Dendrocalamus asper) had been made by Subiyakto et al. (2009). They milled the raw material using disc refiner and stone refiner, continued mixing by ultra turax and high pressure homogenizer for making them homogenized. The particle size was tested by X-Ray Diffraction (XRD) (Li et al., 2001) and Scanning Electron Microscope (SEM) (Nishiyama, 2009).

Research in making nano particle from wood and pulp with chemical process has been conducted since 2000. Micro Crystalline Cellulose (MCC) serves as an additive increased the physical properties of pulp sheet. Table 1 showed that MCC can increase the physical properties of paper thus it acts as the reinforcing agent in paper making.

Recently, Ioelovich and Leykin (2004) have shown the possibility to increase the strength of paper with additive of nanocellulose particle or nanofibrillated cellulose to paper composition. Henrikson et al. (2008) reported the formation of very dense nanopaper (density 1-1,2 $\mathrm{g} / \mathrm{cm}^{3}$ ) from the dispersion of nanofibrillated cellulose that gave Young modulus 10-14 GPa and tensile strength 130-214 MPa. Such sheet has excellent mechanical properties namely Young modulus and tensile strength. These characteristics are similar with regenerated cellulose film (cellophane) and their mechanical properties are 2-5 times higher than common papers formed after conventional beating processes.

An easy adhesion between pulp fibre occurred during papermaking process are challenges for process cellulose on the nanoscale. The hydrogen bonds present on the surface of nanofibres or nanorods (whiskers) cellulose is the key for a better manage ability of these new materials in determining future applications. These applications will be strongly dependent upon the surface properties of nanocellulosic materials and their capability will be compatible with the matrix in which they are processed (Gardner, 2008)

Hydrogen bond set the main rule in making contact between fibres in the paper. It required direct contact between the cellulose fibres to make the hydrogen bond. The roughness of cellulose creates more than ten nanometer distance between fibres, to make the hydrogen bond the distance between fibres should be $0.27-0.30 \mathrm{~nm}$ (Hubbe, 2006). Fibrillation in the beating process is made for making nano fibril bundle due to make the distance requires for hydrogen bond. The additive of nanocellulose in the stock makes the fibrillation easy and decreases the energy of beating. One of the applications of nanocellulose

Table 1. MCC Effect in The Quallity of Paper

\begin{tabular}{cccc}
\hline Sample & Tensile $(\mathrm{kg})$ & $\mathrm{Cobb}_{30 \mathrm{~min}}\left(\mathrm{~g} / \mathrm{m}^{2}\right)$ & MVTR $\left(\mathrm{g} / \mathrm{m}^{2}\right.$.day $)$ \\
\hline Control & 5.5 & 159.5 & 335.2 \\
MCC $(5 \%)$ & 5.7 & 174.7 & 373.4 \\
$\Delta(\%)$ & +3.9 & +9.5 & +11.9 \\
\hline
\end{tabular}

(Ioe Zou and Hsieh, 2007) 
in the specialty papermaking will be conducted and discussed in this paper. Nanocellulose created from Acacia mangium bleached pulp by using disc refiner and homogenized by usingultra turrax. The nanocellulose are measured by X-ray Diffraction (XRD) and Scanning Electron Microscope (SEM), Transmission Electron Microscope (TEM) and Partickel Size Analyser (PSA) (Li et al., 2001).

Acacia mangium is indigenous to Indonesia plantation. The nanocellulose from Acacia mangium bleached pulp is mixed with $90 \%$ Leaf Bleached Kraft Pulp (LBKP) and 10\% Nedle Bleached Kraft Pulp (NBKP) and 95\% LBKP and $5 \%$ NBKP for making specialty paper. Usually the specialty paper consisted of LBKP $20-40 \%$ and NBKP $60-80 \%$, in this paper NBKP was used 5 to $10 \%$ because the addition of nanocellulose will decrease the amount of NBKP. The objective is to use the nanocellulose as an additive to increase the physical properties of paper, reduce the energy of beating and the amount of NBKP.

\section{MATERIALS AND METHOD}

Nanocellulose created from Acacia mangium pulp were taken from PT Tanjung Enim Lestari Palembang. The pulp were placed in water for 24 hours, milled with by disc or stone refiner and homogenized with ultra turrax and homogenizer. The nanocellulose were measured by XRD, SEM, TEM, and Partickel Size Analyser. Research was continued by applying it for making specialty paper. Three variations of particle sizes, $10 \mu \mathrm{m}$,
$5 \mu \mathrm{m}$ and $70 \mathrm{~nm}$ had been done. The paper sheet made by five variations of nanocellulose concentrations $2,4,6,8$ and $10 \%$ and 2 two variations of NBKP $(10 \%$ and $5 \%)$ and two variations of beating degree (300 and $400 \mathrm{~mL}$ CSF). Commercial dry strength agent Cationic Starchhadalso been added for comparison. The physical properties of paper sheet was tested by Indonesian National Standard and its morphology by SEM and XRD, and TEM.

\section{RESULTS AND DISCUSSION}

\section{The Influence of Micro and Nanocellulose Concentration to The Physical Properties of Paper}

In this section we will interpret the influence of particle size, beating degree and composition of long fibre on physical strength of paper sheet. In this research the 3 (three) particle sizes of nanocellulosa have been made; $10 \mu \mathrm{m}, 5 \mu \mathrm{m}$ and $70 \mathrm{~nm}$.

Figure 1 and 2 illustrated the effect of micro and nanocellulose addition on the same pulp composition (5\% NBKP) and the degree of beating ( $300 \mathrm{~mL} \mathrm{CSF})$. So the contribution of strength only resulted from the change of particle size of cellulose. The figure illustrated that the smaller particle size gave the stronger strength. Since the smaller particle size gave larger of surface area which will make higher quantity of hidrogen bond between the fibre and fibre bond.

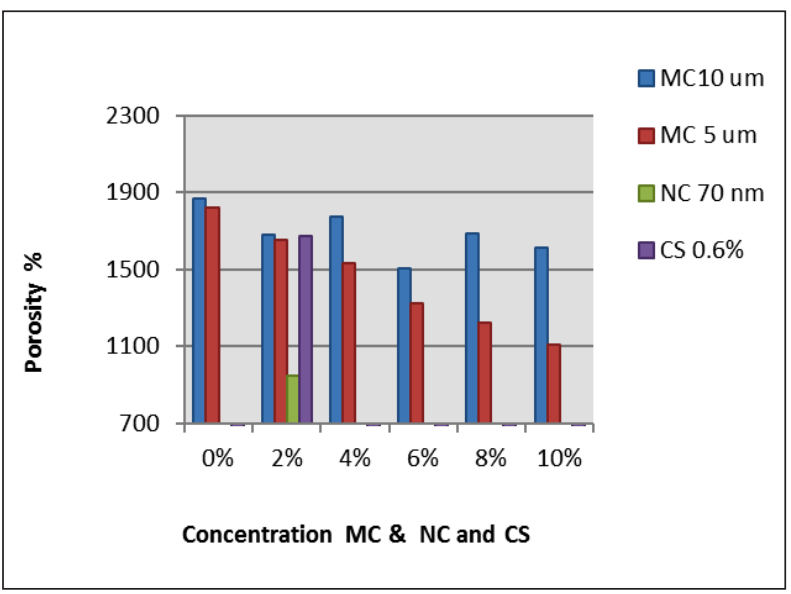

(a)

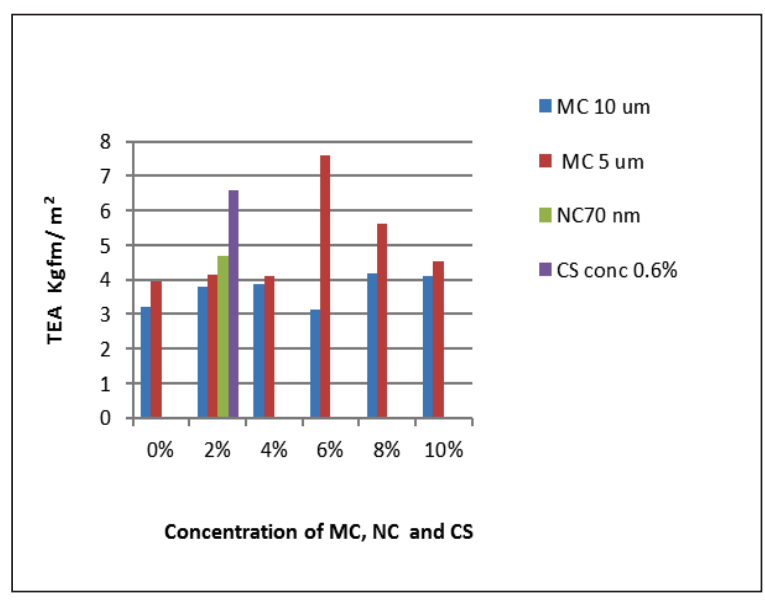

(b)

Figure 1. The Influence of Microcellulose (MC) Nanocellulose (NC) Particle Size and Cationic Starch (CS) to (a) Elongation; (b) Tensile (TEA) 
The strength value will be increased by the increasing fibre bond. It shows the same idea with Gardner (2008) and (Ioe Zou and Hsieh, 2007). Elongation and TEA increased a bit at the beginning and reached the highest value on a dose of $8 \%$ concentration of MC. The increasing of strength indicates that micro and nanocellulose act as the reinforcing agents. The addition of $2 \%$ nanocellulose $(70 \mathrm{~nm})$ increased the elongation by $24 \%$ and TEA by $50 \%$. The result of elongation and TEA is still lower compared with comercial dry strength agent cationic starch.

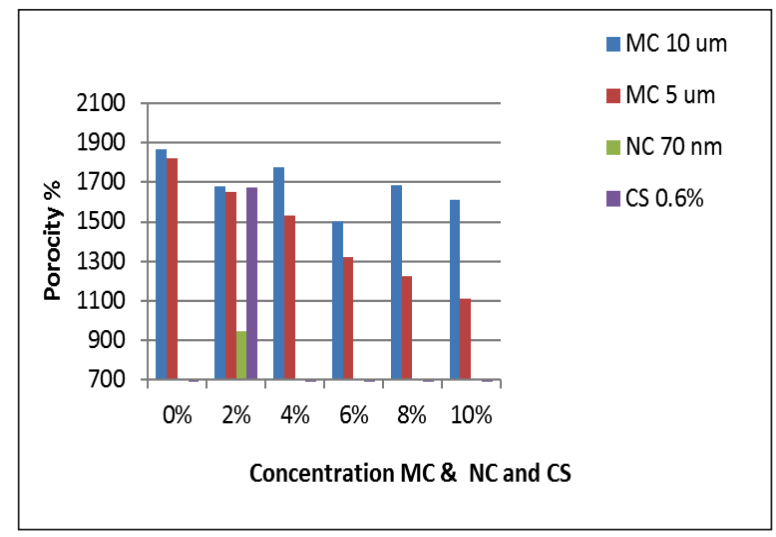

Figure 2. The Influence of Microcellulose (MC) Nanocellulose (NC) Concentration and Particle

Size with Cationic Starch (CS) to Porosity

Figure 2 shows that the porosity decreases with the increasing ofmicrocellulose dose. This is logical as consequence of achieving a higher power; it must be accompanied with a decrease of porosity. Porosity is sharply decline when using smaller size microcellulose. This suggests that the

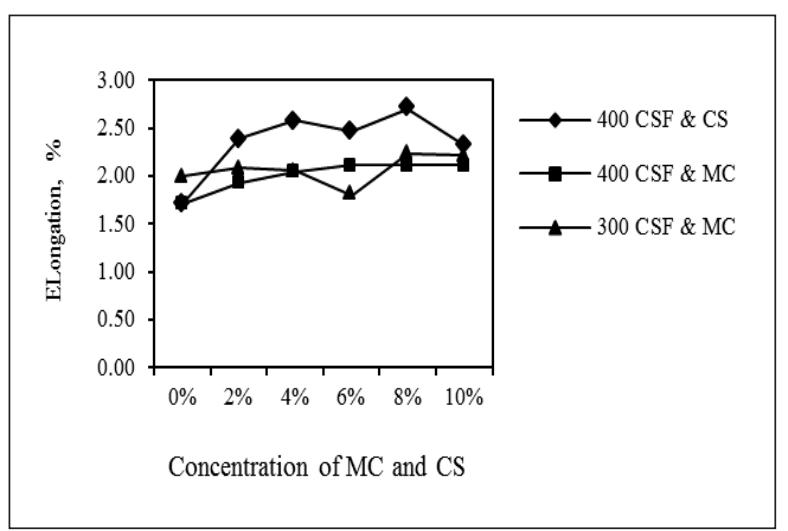

(a) closer construction of the paper sheet and solid. The addition of $2 \%$ nanocellulose $(70 \mathrm{~nm})$ makes the porosity decreased by $50 \%$. Nanocellulose can be applied in making the specialty paper which needs the low porosity such as glassine paper for oily food packaging. The porosity with NC 70 $\mathrm{nm}$ is much lower than that with cationic starch. It means that using nanocellulose is better than cationic starch. The utilization of nanocellulose as reinforcing agent provides several advantages compared with the usual commercial material such as cationic starch and are compatible with fibre, more environmentally friendly, and even its use does not require pretension material as it occurs in commercial materials.

This section shows the influence of beating to elongation and porosity in the sheet with composition of $5 \% \mathrm{NBKP}$ and the addition of microcellulose $10 \mu \mathrm{m}$ or cationic starch. Figure 3(a) shows that the addition microcellulose at different degrees of milling (300 and 400 $\mathrm{mL}$ CSF) showed the same trend of increasing strength with increase of nanocellulose but difference in elongation values. The elongation with $400 \mathrm{~mL} \mathrm{CSF}$ is beating lower than $300 \mathrm{~mL}$ CSF. The beating of $300 \mathrm{~mL}$ CSF needs higher energy of beating than $400 \mathrm{~mL}$ CSF, making the fibre fibrilation and fines higher and hidrogen bond increases. This becomes an important indication of the ability microcellulose act as the inforcing agent, which in this case, milling rate are able to be reduced, an indication of the energy savings with use of microcellulose.Figure $3(\mathrm{~b})$ interpreted different porosity values at 300 and $400 \mathrm{~mL}$ CSF.

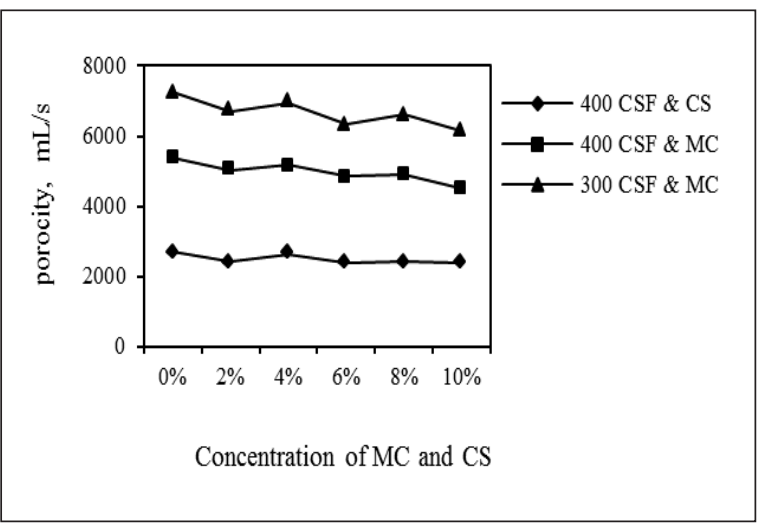

(b)

Figure 3. The influence of Beating, Microcellulose (MC) Nanocellulose (NC) Particle Size and Cationic Starch (CS) to (a) Elongation; (b) to Porosity 
The $300 \mathrm{~mL}$ CSF beating is getting smaller porosity than $400 \mathrm{~mL} \mathrm{CSF}$. The number of fine fibres at $300 \mathrm{~mL}$ CSF is higher than 400 $\mathrm{mL}$ CSF therefore the porosity will be lower at $300 \mathrm{~mL} \mathrm{CSF}$. Decline due to the porosity of paper is increasingly and tightly glued together by fine fibres. The achievement of the porosity is to provide certain strength accelerated by the addition of microcellulose. Addition of microcellulose obviously replaces the role of fine fibre formed during the milling process. Compared with commercial dry strength agent, cationic starch, the porosity using microcellulose is lower than cationic starch (Figure 3b).

This section shows the composition of long fibre interaction with the addition microcellulose and its influence on the paper strength. Long fibres contribute significantly to the strength of paper. But its use is restricted because its more expensive and mostly long fibre in Indonesia is imported. The elongation and porosity in $300 \mathrm{~mL}$ CSF sheet with $5 \% \mathrm{NBKP}$ and $10 \%$ NBKP using variations of concentration of $\mathrm{MC}$ are illustrated at Figure $4 \mathrm{a}$ and $4 \mathrm{~b}$. The length of the fibre contribution is still clearly visible, except at doses microcellulose addition of 2 and $4 \%$. At concentrations of 6 and $8 \%$, contribution of fiber length decreases and as can be seen the higher cracking index value reaches the lower composition of long fiber. The contribution pattern of fibre length changes due to the addition of microcellulose. Therefore the contribution of fibre length on strength can be replaced by microcellulose. In other words, an indication of saving the use of long fibres may occur with the use of microcellulose (Figure 4a). When composition of long fibre is lower, most of the data showed a higher porosity, as shown in
Figure 4(b). This context means that the use of microcellulose could save the use of long fibres as well as enhance the dewatering process in sheet formation in paper machine.

\section{The Posibility of Using Nanocellulose for Improving Paper Making Process at The Mill}

Data on the foregoing discussion suggests that nanocellulose resembles the role of fines on the actual papermaking process. Fines contribute to increasing strength and are formed as a side effect of the refining process. Fines also important for decreasing the break up of sheet at the start up operation in the paper mill.

At the beginning of the paper machine operation or start up, fines are not yet formed, so the paper is often broken when the machine is operated. Then along with the accumulation of fine fibres in the process as result of the white water recycling, the breakup sheet frequency began to decrease and eventually stabilized the process to run smoothly without breaking up the sheet. Achievement of stable conditions can be varied during 20 -10 hour production. In such conditions, the machine does not produce the desired paper. As an illustration, losses that could occur are as follows: if the paper machine speed $1000 \mathrm{~m} / \mathrm{min}$ and a new process stability is achieved in 2 hours, there will be $120,000 \mathrm{~m}$ rejected paper. In this research the addition of nanocellulose in the stock can function as fines to achieve stable condition faster.

Furthermore, based on data in Figure 5, it can be obtained at the possibility during the papermaking process the increased rate of dewatering on the composition of long fibre is lower. This means
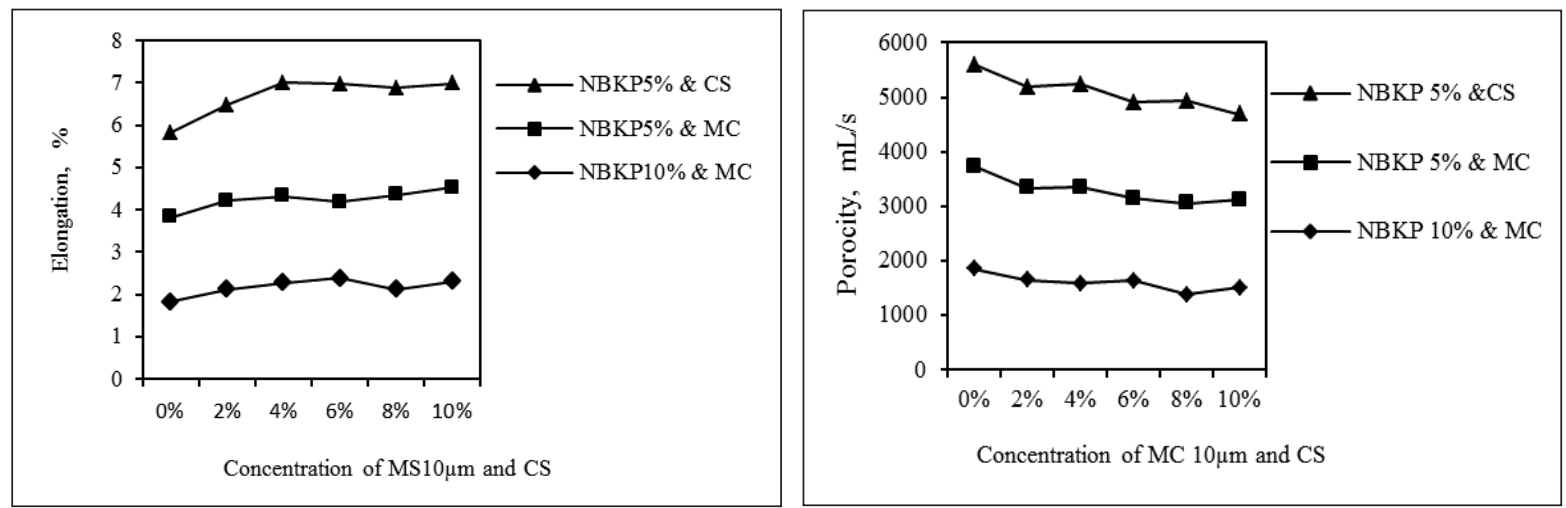

Figure 4. The Influence of Long Fibre, Conc of Microcellulose (MC) Nanocellulose (NC) and Cationic Starch (CS) to (a) Elongation (b) Porosity 
the paper machine productivity can be improved with the use of nanocellulose. In addition, nanocellulose has been made by using available refiner at the paper mill so it can be done right there.

\section{Application of Nanocellulose for Specialty Paper}

Specialty paper is paper with certain properties, very prominent for a particular purpose and needs in small amount of quantity such as security paper with high strength. Specialty paper market segments are also given, and the price is much more expensive than the plain paper. If we notice the characteristic of paper on this research, there are several possible types of specialty paper can be made. By using nanocellulose as filler,the paper will have high strength and low porosity. The security paper needs high strength. Specialty papers that need low porosity are oil-resistant paper such as greaseproof paper, parchment paper, and glassine paper. Oil-resistant paper requires low porosity to control the penetration of the liquid oil into the sheet. Oil-resistant paper is a high quality paper that is normally used for packaging oily products. Therefore security paper and oil-resistent paper can be made by using nanocellulose as filler.

\section{Characterization of Nanocellulose}

Characterization of nanocellulose with Scanning Electron Microscope and Transmission Electron Microscope can be seen at Figure 5 and 6 , respectively. Figure 5a illustrated that the particle sized of MC produced in our research is 5 $\mu \mathrm{m}$. In the paper making the MC made the higher quantity of fibre bonding and make the paper solid as shown in Figure $5 \mathrm{~b}$ an $5 \mathrm{c}$.

Figure 6 illustrated the TEM mycrograph from microcellulose blank and the addition of $6 \%$ MC. The presence MC, which is a small size fibre, causes greater surface area and binds cellulose fibres with another. Increase of surface area will lead to increase of hydrogen bonding
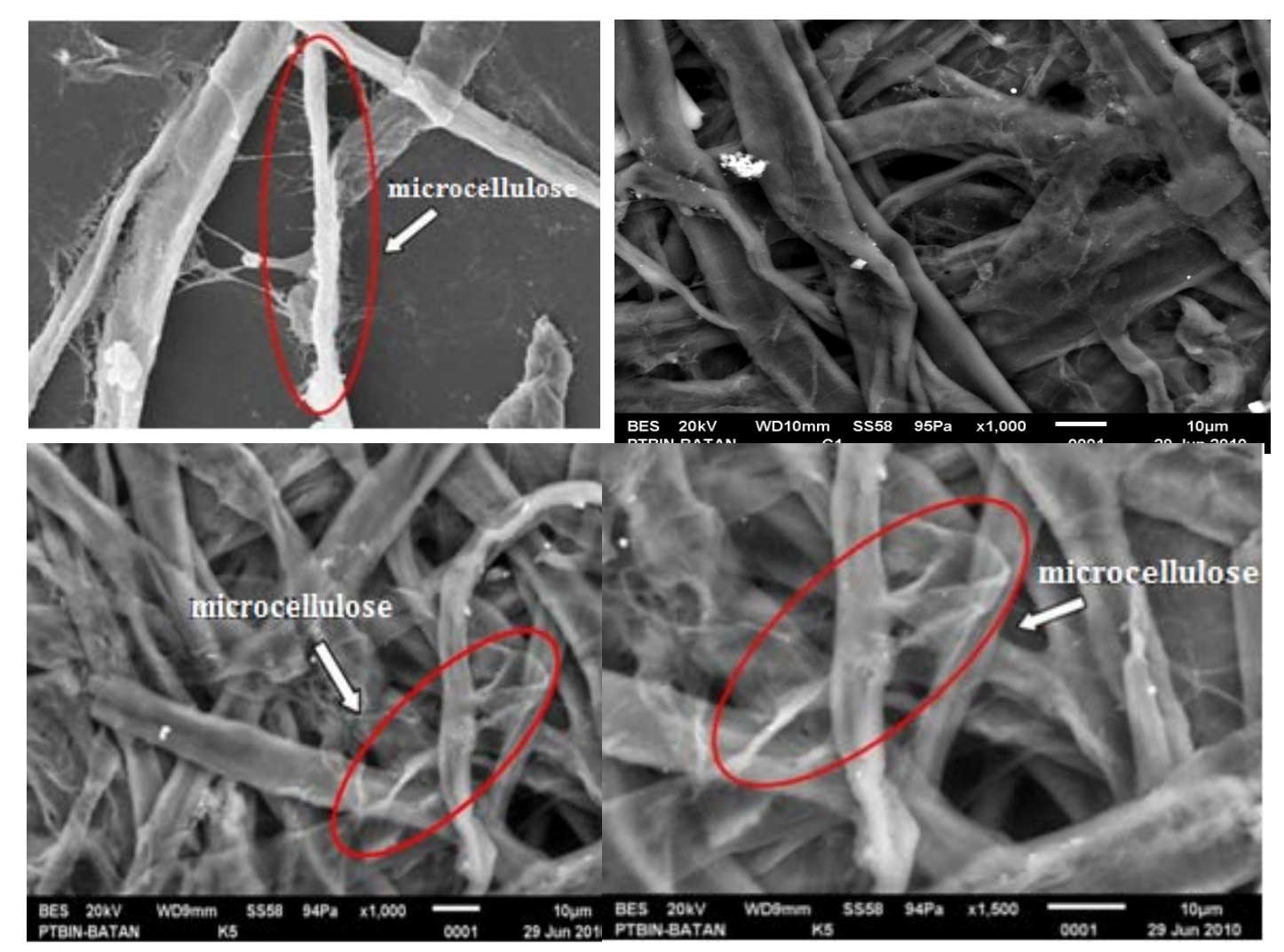

Figure 5. The Micrographs of (a) Microcellulose $5 \mu \mathrm{m}$ SEM Image, Magnification 1000'; (b) Blank LBKP 95\% and 5\% NBKP Magnification 1000'; (c) Blank with 6\% MC $5 \mu \mathrm{m}$ Magnification 1000' and (d) Blank with 6\% MC $5 \mu \mathrm{m}$ Magnification 1500' 


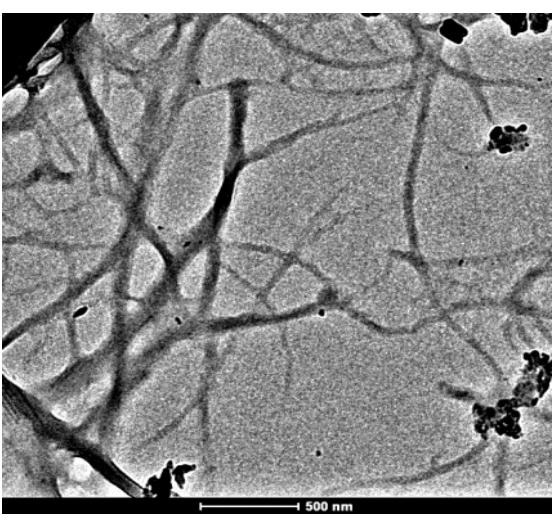

(a)

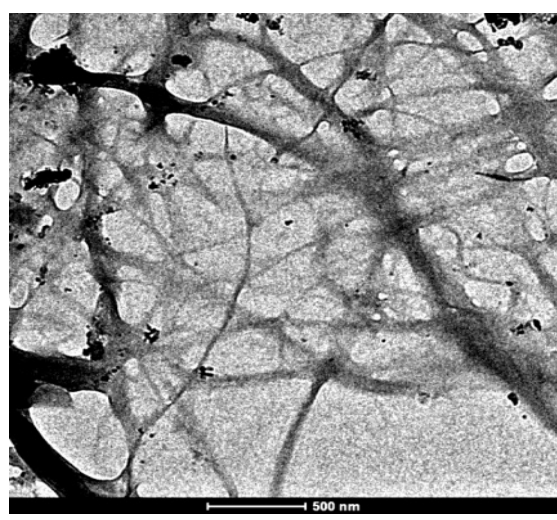

(b)

Figure 6. The Transmission Electron Micrograph of (a) Blank LBKP 95\% and NBKP 5\%; (b) Blank with The Addition of $6 \% \mathrm{MC}$

as well. Figure 11 also shows that $\mathrm{MC}$ fills in the blanks of the blank. This can be seen in the increase of physical properties when compared with blank paper.

The results of micro structure characterization of fibre in samples blank and 6\% MC using TEM can be seen in Figure 6. Figure 6(a) is a blank sheet that consists of short fibres (LBKP) $95 \%$ and the long fibre (NBKP) 5\%. The figure shows the short fibre, long fibre and the empty. Figure $6(\mathrm{~b})$ is blank which is added by $5 \%$ nanocellulose $5 \mu \mathrm{m}$. Soft fibres with a diameter of less than $5 \mu \mathrm{m}$ are interpreted as covering pores that had been empty and increased the fibre bonding. The results supported by the data of porosity which is lower than the blank.

\section{CONCLUSIONS}

In conclusions, nanocellulose filler has a great potential as a reinforcing agent, energy and long fibre saving in the paper making process. Compared to the commercial dry strength agent, cationic starch, nanocellulose provides several advantages such as compatible with fibre, more environmentally friendly, and does not require pretension material as it occurs in commercial materials. Nanocellulose could also support the run ability stabilization in particular paper making process at start-up and reduce the frequency of rupture paper. Nanocellulose can be made in the paper mill by using existing refining facilities and homogenizer as a complement equipment. Nanocellulose is a potential additive material in the manufacture of specialty paper such as greaseproof, glassine, and parchment paper that required very low porosity and security paper that required high strength of paper. The characterization of nanocellulose with SEM and TEM indicates that nanocellulose is interpreted discovering pores and empty area and increased the fibre bonding. The results supported by data of porosity, stating that it is lower than the blank.

\section{ACKNOWLEDGEMENT}

The authors are grateful to the colleagues at Center for Pulp and Paper (CPP) Bandung, Indonesia, Ministry of Industry of Republic of Indonesia, for the support and the encouragement.

\section{REFERENCES}

Bahar, N. Tjahjono J., Hidayat T., Yuwono S., Kardiansyah T. 2010 The Application of Nanocellulose as Reinforcing Agent for Paper Making, Proceedings International Seminar on Fundamental and Application of Chemical Engineering 2010, Bali 3 - 4 November 2010.

Gardner, Douglas J. 2008 Adhesion and Surface Issues in Cellulose and Nanocellulose Journal of Adhesion Science and Technology (22) 545-567, USA

Ioe Zou, Y and Hsieh, J.S. 2007 Microcrystalline Cellulose (MCC) for Papermaking and Surface Sizing. International Conference for the forest Product Industry. Knoxville.

Henrikson M., Berglund L.A, Isaksson P., Lindstrom T., Nishino, T. 2008. Cellulose nano - paper structures and high toughness. Biomeoleculares; 9: 1579-1585 
Hubbe M.A., 2006 Bonding between cellulosic fibers and the absence and presence of dry - strength agent - A review BioResource; 1(2): 281-318

Ioelovich M., Leykin. 2004. Nano-cellulose and its Application J. SITA 6 (3) 17-24. Israel Press. Atlanta

Klush, L. R. K. 1976. Paper and Paper Converting Industries. Small Business Publication. New Delhi

Kocurek M.J., 1983 Paper Machine Operation in Pulp and Paper Manufacture. TAPPI

Li, X., Ding E., Li G. 2001 A Method of Preparing Spherical Nano-crystal Cellulose with Mixed Crystalline Forms of Cellulose I and II. Chinese Journal of Polymer Science. Spriger-Verlag
Nishiyama, Y. 2009. Structure and properties of the cellulose microfibril, J. Wood Sci. 55, 241-249

Subyakto, Euis Hermiati, Yanto D. H. Y., Fitria, Budiman I, Masruchin N. Subiyanto B. 2009. Development of process to produce cellulose nanofiber from sisal (Agave sisalana) and betung bambu (Dendrocalamus Asper) Prosiding Seminar Teknologi Pulp dan Kertas 2009;20-28 